\title{
Photoperiod and temperature regulation of diapause egg production in Acartia bifilosa from Southampton Water
}

\author{
Fay E. Chinnery ${ }^{1,2, *}$, John A. Williams ${ }^{1}$ \\ ${ }^{1}$ University of Southampton, School of Ocean and Earth Science, Empress Dock, Southampton, Hampshire SO14 3ZH, UK \\ ${ }^{2}$ Present address: Somers Cancer Research Building, Mail Point 824, Southampton General Hospital, Southampton SO16 6YD, UK
}

\begin{abstract}
In Southampton Water the copepod Acartia bifilosa presents a diapause reproductive strategy, where there is a switch from subitaneous to diapause egg production around May, prior to the species' disappearance from the water column between June and October. The effect of temperature and photoperiod on the production of diapause eggs by $A$. bifilosa was studied in an attempt to determine the primary cues for its summer diapause. A parallel study on the effect of temperature on metabolic efficiency of $A$. bifilosa and the non-diapause species $A$. discaudata, defined by the species' 'scope for growth' (SfG), was examined as a potential, ultimate reason behind the diapause stage. Photoperiod was identified as the primary proximate cue that induced diapause in A. bifilosa, and this response was temperature-mediated. Diapause was triggered by a 13:11 h light:dark photoperiod (day length), corresponding to a late-April photoperiodic regime, and resting eggs were produced even at temperatures as low as $5^{\circ} \mathrm{C}$. A very low number of diapause eggs were, however, also produced after $6 \mathrm{~d}$ at a 12:12 h light:dark photoperiod at elevated temperatures between 14 and $20^{\circ} \mathrm{C}$, but the mean percentage produced was significantly less $(\mathrm{p}<0.05)$ than under the longer day lengths. The ultimate cause of the over-summering strategy of $A$. bifilosa is currently unknown, but the SfG assay indicated that at $10^{\circ} \mathrm{C}$, SfG was twice that at 20 or $5^{\circ} \mathrm{C}$, and so it may diapause to avoid the higher temperatures in summer. This pattern contrasted with the SfG of $A$. discaudata, which suggested a simple, positive relationship with temperature. In the field, competition is greatly reduced in the winter months, so A. bifilosa has a better chance of survival, even with its lower SfG.
\end{abstract}

KEY WORDS: Acartia bifilosa $\cdot$ Diapause $\cdot$ Egg production $\cdot$ Photoperiod $\cdot$ Scope for growth

Resale or republication not permitted without written consent of the publisher

\section{INTRODUCTION}

The abundance and even presence in the water column of most copepod species varies on a seasonal basis, a pattern which is most typical in temperate coastal waters, where environmental fluctuations are greater than in tropical or open ocean waters (Grice \& Marcus 1981). Diapause eggs have been documented in several temperate neritic copepods (Zillioux \& Gonzalez 1972, Grice \& Gibson 1975, 1977, Kasahara \& Uye 1979, Johnson 1980) as a method of sustaining a population through adverse environmental conditions, and providing life-cycle stability by allowing a species' life-cycle to synchronise with the environment's seasonal rhythm (Alekseev \& Starobogatov 1996).

Within Southampton Water, on the south coast of the UK, the calanoid copepod Acartia bifilosa appears in the water column from November/December to June (Conover 1957, Raymont \& Carrie 1964), and diapauses over summer (Castro-Longoria \& Williams 1999). It is common in many European estuaries (Irigoien \& Castel 1995, Sautour \& Castel 1995) and is also known to over-summer as the egg phase in the Baltic (Viitasalo 1992). Despite these studies, very little is known about its diapause behaviour, in particular the initial cue, and the ultimate reason behind this life- 
style strategy. Castro-Longoria \& Williams (1999) reported that Southampton Water A. bifilosa produced 2 morphologically distinct egg-types: a smooth subitaneous egg and a diapause egg that is characteristically covered in spines. Subitaneous eggs are laid during the first months of the copepod's presence in the water column, with diapause eggs produced only in the 2 month period prior to the disappearance of $A$. bifilosa from the water column between June and October. It is unusual for a marine species to over-summer, because it is a costly strategy that removes the species from the water column at a time that is generally considered most advantageous in terms of food availability.

The ultimate cause of such seasonality is unknown, possibly it is an attempt to avoid higher temperatures, a food bottleneck (Santer \& Lampert 1995), overcrowding (Ban \& Minoda 1994) or predators (Slusarczyk 1995). The cause is unlikely to be food scarcity because the phytoplankton bloom starts in March/April and extends until autumn (Kifle 1992). Acartia bifilosa diapause coincides with the maximum population density of gelatinous predators Aurelia aurita and Pleurobranchia pileus in Southampton Water (Lucas \& Williams 1995). A. bifilosa is less fecund than other members of the genus, and egg-hatching times are also longer (Castro-Longoria 1998), so A. bifilosa would clearly have a reduced capacity for recovery from predator impact. However, real-time cues, like the presence of predators in the water column, would come too late for $A$. bifilosa to avoid the threat by the production of diapause eggs. Clearly, it must rely on proximate cues that provide a reliable forecast of future conditions (Slusarczyk 1995). Temperature is one of the most commonly recognised cues for controlling copepod diapause (Uye 1985, Viitasalo 1992, Ban \& Minoda 1994), but photoperiodic effect has only been studied comprehensively in Labidocera aestiva (Marcus 1979, 1980, 1982). In contrast to A. bifilosa, L. aestiva presents a conventional winter diapause. Laboratory investigations showed that short days $(8: 16 \mathrm{~h}$ light:dark) resulted in $L$. aestiva diapause egg production at all temperatures (Marcus 1979, 1980, 1982).

The potential for photoperiod to play a significant part in inducing Acartia bifilosa diapause egg production will be examined in this paper. Considering reproductive regulators, Castro-Longoria \& Williams (1999) hypothesised that $A$. bifilosa fecundity might also be limited to some degree by temperature, such that adult intolerance of higher temperatures may be the cause of this species' unusual reproductive strategy. In an attempt to explain the ultimate cause behind $A$. bifilosa summer diapause, and as a way of understanding the copepod's winter performance, the ability of adult $A$. bifilosa to cope with temperature stress will be looked at using the scope for growth (SfG) assay, based on the energy equation of Winberg (1960). The SfG is a measure of the energy balance between the energy assimilated and the metabolic output of an individual. It is used to give an indication of how much energy is available for growth and reproduction, both key components of fitness (Bayne et al. 1985). This parallel study to the photoperiod investigation will highlight the copepod's metabolic performance and the amount of energy available to the copepod at temperatures reflecting the conditions of winter, spring/autumn and summer. The SfG results will be compared with those of $A$. discaudata, a species that has a very similar spatial distribution to that of $A$. bifilosa within Southampton Water. In contrast to $A$. bifilosa, it does not diapause over summer or winter, and is present in Southampton Water all year round, with maximum density in summer and very low numbers during winter (Castro-Longoria 1998). The SfG assay will indicate the optimum temperature for A. bifilosa and $A$. discaudata.

\section{MATERIALS AND METHODS}

Day length and temperature were tested as potential exogenous stimuli controlling the reproductive shift of Acartia bifilosa from subitaneous to diapause egg production. During March, A. bifilosa samples were collected from 1 to $5 \mathrm{~m}$ depth at Calshot buoy, at the mouth of Southampton Water, using a $120 \mu \mathrm{m}$ mesh net. Acartia spp. do not show apparent diel vertical migration but are known to be highly concentrated in the surface layers in the afternoon (Checkley et al. 1992). Ambient temperature, light and salinity conditions were $6^{\circ} \mathrm{C}$, a $12: 12 \mathrm{~h}$ light:dark cycle, and 33 respectively, and females in the field were not producing diapause eggs (Castro-Longoria \& Williams 1999).

Temperature and photoperiod regulation of Acartia bifilosa diapause egg production. The effect of temperature and photoperiod on A. bifilosa diapause egg production was investigated using experimental incubation regime combinations of $5,10,14$ and $18^{\circ} \mathrm{C}$ and $12: 12,13: 11$ and $14: 10 \mathrm{~h}$ light:dark photoperiods. Experiments were conducted at low light levels approximating field light-intensity levels. Experimental populations of 20 females were introduced immediately, without prior acclimation, into individual incubation chambers (Chinnery 2002) maintained at each of the light/temperature regimes. Individuals were not acclimated to experimental temperature and photoperiod conditions, as the intention was to examine the rapidity of any change to diapause egg production. The presence or absence of males did not influence fecundity or egg viability of female A. clausi collected from the field (Ianora et al. 1996), and so none were introduced to the incubation chambers. These cham- 
bers were plastic cylinders closed at one end with a $200 \mu \mathrm{m}$ mesh, and supported in a 11 beaker filled with $600 \mathrm{ml}$ of $26 \mu \mathrm{m}$ filtered seawater (30 to 32 salinity). Three replicates were conducted for each incubation regime. Food was provided immediately and then at $2 \mathrm{~d}$ intervals in the form of $10 \mathrm{ml}$ of Isochrysis galbana in its exponential growth phase to give excess food concentrations of $1 \times 10^{5}$ cells $\mathrm{ml}^{-1}$. This concentration was comparable to other feeding studies (Ianora et al. 1996, Castro-Longoria \& Williams 1999), and in excess of the maximum ingestion rates reported for Acartia sp. (Nival \& Nival 1976). During the $8 \mathrm{~d}$ experimental period, eggs were collected every $2 \mathrm{~d}$. The incubation cylinders containing the copepods were carefully removed, and the chamber water was filtered through a $45 \mu \mathrm{m}$ mesh to capture the eggs. The cylinders were then put into another incubation chamber containing clean, preacclimated water and fresh food. Eggs were examined using a binocular microscope and the diapause:subitaneous egg ratio produced at each $2 \mathrm{~d}$ interval was recorded. This facilitated comparisons between samples and replicates. After collection, both subitaneous and diapause eggs were stored in large petri dishes in $20 \mathrm{ml}$ of seawater (30 to 32 salinity) at $18^{\circ} \mathrm{C}$ for a further $8 \mathrm{~d}$ and hatch success was monitored.

Scope for growth assay. Acartia bifilosa and A. discaudata sub-samples were also immediately placed in feeding chambers, similar to the incubation chambers, at $5^{\circ} \mathrm{C}$, which reflected field ambient-temperature, and at a light regime of 12:12 h light:dark. They were conditioned to the experimental Isochrysis food source of $\sim 1 \times 10^{5}$ cells ml ${ }^{-1} \mathrm{~d}^{-1}$ for $24 \mathrm{~h}$ (Tester \& Turner 1990). Individuals were taken from these sub-samples to determine individual dry weight for adult female $A$. bifilosa and $A$. discaudata. Before conducting any part of the SfG assay, all experimental animals were preacclimated for $24 \mathrm{~h}$ to the appropriate experimental temperature of 5 (winter), 10 (spring/autumn) or $20^{\circ} \mathrm{C}$ (summer) at a light regime of 12:12 h light:dark. The temperatures were taken from a year-long sampling programme conducted in Southampton Water (2001-2002), and each is representative of its season.

The 'cell count method' (Gauld 1951, Frost 1972) was used to determine feeding rate. Five replicates of Acartia bifilosa and $A$. discaudata were conducted for each experimental temperature. Five adult females were placed in individual $500 \mathrm{ml}$ vials of $26 \mu \mathrm{m}$ filtered seawater at 32 salinity with Isochrysis added to give an initial food concentration of $\sim 1 \times 10^{5}$ cells $\mathrm{ml}^{-1}$. The vials were maintained in constant darkness (Checkley et al. 1992, Irigoien et al. 1993, Irigoien \& Castel 1995) and at experimental temperatures for $24 \mathrm{~h}$ on a plankton wheel set at 0.5 revolutions $\mathrm{min}^{-1}$. The copepods were then carefully pipetted into fresh vials containing
Isochrysis and run over $6 \mathrm{~h}$. The concentration of algal cells in standard and running controls, together with the experimental vials, were determined and feeding rate was converted, by the derived calorific value of the algae $1.09 \times 10^{-6} \mathrm{~J} \mathrm{cell}^{-1}$, to express feeding as $\mathrm{J}$ mg dry $\mathrm{wt}^{-1} \mathrm{~d}^{-1}$.

Assimilation efficiency was calculated using the work of Conover (1966). Three replicate experimental populations of 25 Acartia discaudata or 25 A. bifilosa, preacclimated to experimental temperatures and experimental diet, were each placed in individual feeding chambers for $24 \mathrm{~h}$, and samples of Isochrysis and faecal pellets were dried $\left(60^{\circ} \mathrm{C}\right.$ for $\left.24 \mathrm{~h}\right)$, weighed and ashed $\left(500^{\circ} \mathrm{C}\right.$ for $\left.3 \mathrm{~h}\right)$ to determine assimilation efficiency.

Respiration rates of preacclimated and fed experimental populations of either 5 Acartia bifilosa or A. discaudata females were measured over $6 \mathrm{~h}$ using the Winkler procedure (Crisp 1971, Lucas 1996) for determination of dissolved oxygen. Oxygen consumption, initially expressed as ml $\mathrm{O}_{2} \mathrm{l}^{-1} \mathrm{mgdry} \mathrm{wt}^{-1} \mathrm{~d}^{-1}$, was converted (Crisp 1971, Bayne et al. 1985, Lucas 1996) to give $\mathrm{J}$ mg dry $\mathrm{wt}^{-1} \mathrm{~d}^{-1}$. Five replicates were conducted for each species at each experimental temperature.

The copepods were assumed to be ammonotelic, such that the losses of organic matter through metabolism of protein were estimated from the rate of ammonium excretion (Abou Debs 1984, Checkley et al. 1992), as ammonia constitutes 80 to $90 \%$ of excreted nitrogen in Acartia tonsa (Kiørboe et al. 1985). The experiments were conducted in the light, as copepod ammonium excretion was maximal during the daytime (Checkley et al. 1992). Excretion rate was measured spectrophotometrically as dissolved $\mathrm{NH}_{3}-\mathrm{N}$ following Solorozano (1969). Five experimental replicates of 10 preacclimated and fed adult females of both Acartia bifilosa and A. discaudata were run for $6 \mathrm{~h}$. Excretion was initially expressed as $\mu \mathrm{g} \mathrm{NH}_{4}-\mathrm{N}$ mg dry $\mathrm{wt}^{-1} \mathrm{~d}^{-1}$ and then converted (Elliott \& Davison 1975, Bayne et al. 1985, Lucas 1996) to $\mathrm{J}$ mg dry $\mathrm{wt}^{-1} \mathrm{~d}^{-1}$.

Significance was tested by ANOVA and set at the $\mathrm{p}<0.05$ level. Assimilation efficiency was analysed by $t$-test and significance set at $\mathrm{p}<0.01$ level.

\section{RESULTS}

\section{Temperature and photoperiod regulation of Acartia bifilosa diapause egg production}

There was a clear threshold photoperiod of 13:11 h light:dark, equivalent to a late April natural photoperiod, which initiated an increase in the number of diapause eggs laid (Table 1). Copepods at the threshold photoperiod also produced far fewer eggs (45 to 97) 
Table 1. Acartia bifilosa. Mean percentage of diapause eggs produced $( \pm 1 \mathrm{SD})$. Percentage data are not cumulative. -: no reading taken; $\mathrm{n}$ : total number of eggs produced from all replicates over each $2 \mathrm{~d}$ experimental period

\begin{tabular}{|c|c|c|c|c|c|}
\hline \multirow{2}{*}{ Photoperiod (h light:dark) } & \multirow{2}{*}{ Day } & \multicolumn{4}{|c|}{ — Temperature $\left({ }^{\circ} \mathrm{C}\right)$} \\
\hline & & 5 & 10 & 14 & 18 \\
\hline \multirow{4}{*}{$12: 12$} & 2 & & - & - & - \\
\hline & 4 & & $0(\mathrm{n}=30)$ & $0(\mathrm{n}=72)$ & $0(\mathrm{n}=44)$ \\
\hline & 6 & & $0(\mathrm{n}=63)$ & $1.1 \pm 1.91(\mathrm{n}=72)$ & $1.43 \pm 2.48(\mathrm{n}=53)$ \\
\hline & 8 & & $0(\mathrm{n}=30)$ & $23.0 \pm 39.8(n=50)$ & $14.4 \pm 24.8(n=30)$ \\
\hline \multicolumn{2}{|l|}{ Total number of eggs produced } & & 123 & 194 & 127 \\
\hline \multirow[t]{4}{*}{$13: 11$} & 2 & $31.9 \pm 18.0(\mathrm{n}=28)$ & $43.9 \pm 2.84(\mathrm{n}=36)$ & $41.2 \pm 5.12(\mathrm{n}=49)$ & $32.7 \pm 18.9(\mathrm{n}=30)$ \\
\hline & 4 & & - & - & - \\
\hline & 6 & $93.3 \pm 11.5(n=14)$ & $77.6 \pm 25.4(\mathrm{n}=39)$ & $61.1 \pm 9.64(\mathrm{n}=11)$ & $61.1 \pm 9.64(\mathrm{n}=9)$ \\
\hline & 8 & $93.3 \pm 11.5(\mathrm{n}=10)$ & $100 \pm 0.00(\mathrm{n}=22)$ & $83.3 \pm 28.9(n=6)$ & $91.7 \pm 14.4(\mathrm{n}=6)$ \\
\hline Total number of eggs produced & & 52 & 97 & 66 & 45 \\
\hline \multirow[t]{4}{*}{$14: 10$} & 2 & & $13.7 \pm 20.7(n=68)$ & $3.7 \pm 6.4(\mathrm{n}=63)$ & $10.6 \pm 15.7(\mathrm{n}=125)$ \\
\hline & 4 & & $41.3 \pm 11.5(\mathrm{n}=76)$ & $40.6 \pm 4.9(\mathrm{n}=55)$ & $46.3 \pm 11.6(\mathrm{n}=22)$ \\
\hline & 6 & & $60.2 \pm 18.7(\mathrm{n}=84)$ & $63.9 \pm 25.5(n=48)$ & $54.9 \pm 4.6(\mathrm{n}=39)$ \\
\hline & 8 & & $65.5 \pm 14.2(\mathrm{n}=158)$ & $67.3 \pm 19.9(\mathrm{n}=54)$ & $84.1 \pm 9.3(\mathrm{n}=43)$ \\
\hline Total number of eggs produced & & & 386 & 220 & 229 \\
\hline
\end{tabular}

during the $8 \mathrm{~d}$ experimental period than experimental populations placed under a 12:12 (123 to 194) or 14:10 (220 to 386) h light:dark period. Even allowing for the missed sampling period on Day 4, the total number of eggs produced at a 13:11 h light:dark period at each temperature was less than a third of that at the other photoperiods. Adult mortality was negligible at all temperatures $(<5 \%)$, and showed no particular pattern. Acartia bifilosa egg production rates in all of the replicates ranged from 0.15 eggs female $\mathrm{f}^{-1} \mathrm{~d}^{-1}$ to 3.95 eggs female ${ }^{-1} \mathrm{~d}^{-1}$.

The total number of eggs removed from an incubation chamber was determined for most, but not all, $2 \mathrm{~d}$ periods. The number of eggs produced in a $2 \mathrm{~d}$ period ranged from 6 to 158 eggs (Table 1), but there was no significant or consistent pattern with regard to the experimental incubation temperature, although the higher, $18^{\circ} \mathrm{C}$, incubation usually produced the lowest number of eggs under each photoperiod tested. The range in egg numbers produced had no obvious influence on the proportion of subitaneous and diapause eggs. There was an immediate shift in egg-type production between the 12 and $13 \mathrm{~h}$ day lengths (Table 1), and after only $2 \mathrm{~d}$ there was a clear and significant $(p<0.05)$ difference between the mean percentage of diapause eggs produced under a 12:12 and 13:11 h light:dark period at all temperatures.

Temperature appeared to influence the egg-type response, as, even under a 12:12 h light:dark period, a small number of diapause eggs were produced after $8 \mathrm{~d}$ at the higher temperatures of 14 and $18^{\circ} \mathrm{C}$ (Table 1). The $2 \mathrm{~d}$ mean percentage of diapause eggs produced at this photoperiod was, however, significantly less $(p<$
0.05) than that produced under 13:11 and 14:10 h light:dark periods. At all temperatures tested, the percentage of diapause eggs produced at 13:11 and 14:10 h light:dark periods increased over the period of investigation, and after $8 \mathrm{~d}$, diapause egg production was $100 \%$ in some replicates. After 8 d under a 13:11 h light:dark period, the difference in the mean percentages of diapause eggs produced at each temperature was not statistically significant (ANOVA $F_{3,8}<1$ ). The diapause response was not overtly temperature-mediated at this sensitive photoperiod because spiny diapause eggs were produced even at temperatures as low as $5^{\circ} \mathrm{C}$. Equally, although the mean percentages of photoperiod-collated diapause egg production after $8 \mathrm{~d}$ at 10,14 and $18^{\circ} \mathrm{C}$ were $55.2 \pm 44.6,57.9 \pm 37.9$ and $63.3 \pm 39.9 \%$, respectively (Fig. 1), the results were not statistically significant (ANOVA $F_{2,24}<1$ ).

The types of egg produced were affected primarily by photoperiod (Fig. 2), as there was no significant temperature effect within each photoperiod regime, even at the threshold day length of 13:11 h light:dark (Table 1). The temperature data were collated (Fig. 2) to highlight the significance of the photoperiod. The resulting mean percentage of diapause egg production over $8 \mathrm{~d}$ at light:dark photoperiods of 12:12, 13:11 and 14:10 h (temperature-collated data) were $12.4 \pm 25.5$, $92.1 \pm 15.9$ and $72.3 \pm 15.8 \%$ respectively, and were significantly different (ANOVA $F_{2,24}=5.61, \mathrm{p}<0.05$ ). The 13:11 $\mathrm{h}$ light:dark regime was clearly the threshold photoperiod, presenting the highest percentage of diapause eggs produced after $8 \mathrm{~d}$, with similar results for the 14:10 h light:dark experimental programme. 


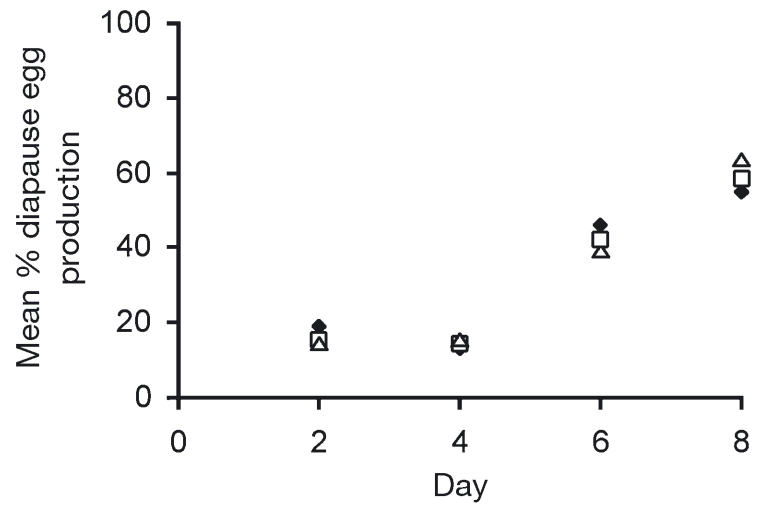

Fig. 1. Acartia bifilosa. Effect of temperature on diapause egg production (photoperiod-collated data). Photoperiod data (Table 1) have been combined and a single mean determined for each temperature $\left(\bullet=10, \square=14\right.$, and $\left.\Delta=18^{\circ} \mathrm{C}\right)$

Inevitably, a mixture of subitaneous and diapause eggs was collected from each incubation chamber, and so it was not clear whether, like Labidocera aestiva females (Marcus 1982), individual Acartia bifilosa females can produce both smooth and spiny eggs at the same time, or if the switch was a complete one with females either producing only diapause eggs or subitaneous eggs. There was no evidence, however, of the production of a spiny subitaneous egg as reported by Castro-Longoria \& Williams (1999). The vast majority of subitaneous $A$. bifilosa eggs hatch within $5 \mathrm{~d}$ under good temperature and salinity conditions $\left(>10^{\circ} \mathrm{C}\right.$ and $>25$ salinity) (Castro-Longoria \& Williams 1999). None of the 'spiny' eggs collected hatched within the $8 \mathrm{~d}$ observation period, suggesting the absence of this egg-type.

\section{Scope for growth assay}

Considering the metabolic performance of the congeners, Acartia discaudata ingestion rate clearly increased with increasing temperature (Table 2), suggesting that it was more active at higher temperatures,

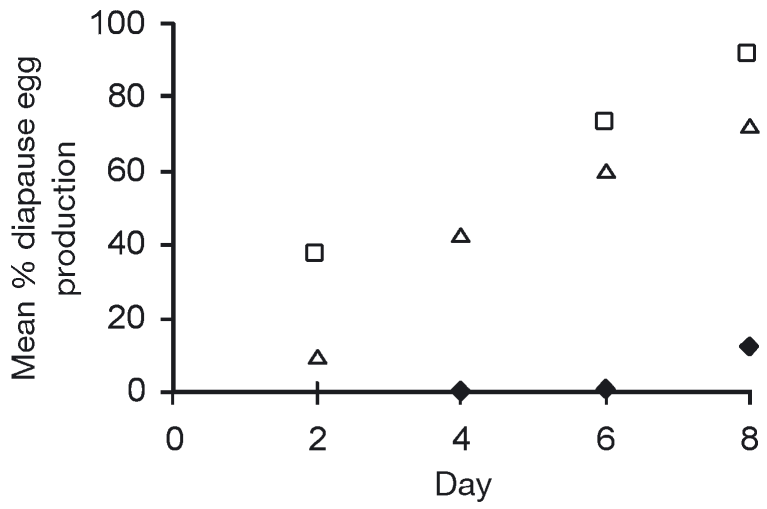

Fig. 2. Acartia bifilosa. Diapause egg production (temperaturecollated data). Temperature data (Table 1) have been combined and a single mean determined for each photoperiod $(\bullet=12: 12, \square=13: 11$, and $\Delta=14: 10$ h light:dark photoperiods)

and its feeding rate at $20^{\circ} \mathrm{C}$ was significantly greater $(\mathrm{p}<0.05)$ than at $5^{\circ} \mathrm{C}$. In contrast, $A$. bifilosa ingested more food at $10^{\circ} \mathrm{C}$, although the difference in feeding rate recorded at each experimental temperature was not significant. Comparing the 2 congeners, there was no difference in feeding rate at $5^{\circ} \mathrm{C}$, but $A$. bifilosa had a significantly $(\mathrm{p}<0.01)$ higher feeding rate at $10^{\circ} \mathrm{C}$, whereas A. discaudata ingested significantly $(p<0.01)$ more food at $20^{\circ} \mathrm{C}$.

There was a clear difference in the percent assimilation measured for Acartia bifilosa (Table 2), with a significantly ( $p<0.01$ ) lower assimilation percentage of $64.9 \%$ at $20^{\circ} \mathrm{C}$, compared with the highest assimilation efficiency, $87.25 \%$, recorded at $10^{\circ} \mathrm{C}$. Although the percent assimilation of $A$. discaudata consistently increased with temperature, from $73.4 \%$ at $5^{\circ} \mathrm{C}$ to $82.5 \%$ at $20^{\circ} \mathrm{C}$, there was no significant difference between these values. The only significant inter-species difference was at $20^{\circ} \mathrm{C}$, where $A$. discaudata had the higher $(\mathrm{p}<0.01)$ assimilation efficiency. Reflecting ingestion rate and assimilation efficiency patterns (Table 2), the amount of energy assimilated increased at each species' optimum temperature of 10 and $20^{\circ} \mathrm{C}$ for $\mathrm{A}$. bifilosa and A. discaudata respectively (Fig. 3).

Table 2. Acartia bifilosa and A. discaudata scope for growth (mean $\pm 1 \mathrm{SD}$ ) at 5, 10 and $20^{\circ} \mathrm{C}$. T: temperature; C: energy ingested; A (\%): assimilation efficiency; A: energy assimilated; R: energy respired; U: energy excreted; P: scope for growth; T, A, R and U values all in $\mathrm{J}$ mg dry $\mathrm{wt}^{-1} \mathrm{~d}^{-1}$

\begin{tabular}{|c|c|c|c|c|c|c|c|}
\hline Species & $\mathrm{T}\left({ }^{\circ} \mathrm{C}\right)$ & $\mathrm{C}$ & $\mathrm{A}(\%)$ & A & $\mathrm{R}$ & $\mathrm{U}$ & $\mathrm{P}$ \\
\hline \multirow[t]{3}{*}{ A. bifilosa } & 5 & $30.01 \pm 9.27$ & $79.3 \pm 4.20$ & 23.80 & $17.47 \pm 8.18$ & $0.043 \pm 0.003$ & 6.28 \\
\hline & 10 & $38.76 \pm 6.36$ & $87.2 \pm 5.09$ & 33.80 & $18.08 \pm 7.31$ & $0.044 \pm 0.003$ & 15.67 \\
\hline & 20 & $35.01 \pm 12.7$ & $64.9 \pm 2.84$ & 22.72 & $15.42 \pm 6.48$ & $0.058 \pm 0.007$ & 7.24 \\
\hline \multirow[t]{3}{*}{ A. discaudata } & 5 & $27.85 \pm 9.55$ & $73.4 \pm 3.80$ & 20.44 & $15.66 \pm 1.38$ & $0.038 \pm 0.001$ & 4.74 \\
\hline & 10 & $31.50 \pm 7.26$ & $80.8 \pm 2.85$ & 25.45 & $17.28 \pm 4.26$ & $0.046 \pm 0.011$ & 8.13 \\
\hline & 20 & $42.50 \pm 6.78$ & $82.5 \pm 2.61$ & 35.06 & $12.97 \pm 8.10$ & $0.048 \pm 0.003$ & 22.04 \\
\hline
\end{tabular}


For both species, respiration was responsible for the majority of the energy 'used' within the SfG definition (Table 2), representing 53.5 to $73.4 \%$ of the energy assimilated for Acartia bifilosa, and 37.0 to $76.6 \%$ for A. discaudata, corresponding to 15.42 to 18.08 and 12.97 to $17.28 \mathrm{~J}$ mg dry $\mathrm{wt}^{-1} \mathrm{~d}^{-1}$ respectively. Unusually, both congeners lost most energy through respiration at $10^{\circ} \mathrm{C}$, and the least energy at $20^{\circ} \mathrm{C}$. For A. bifilosa this followed a pattern reflecting its feeding
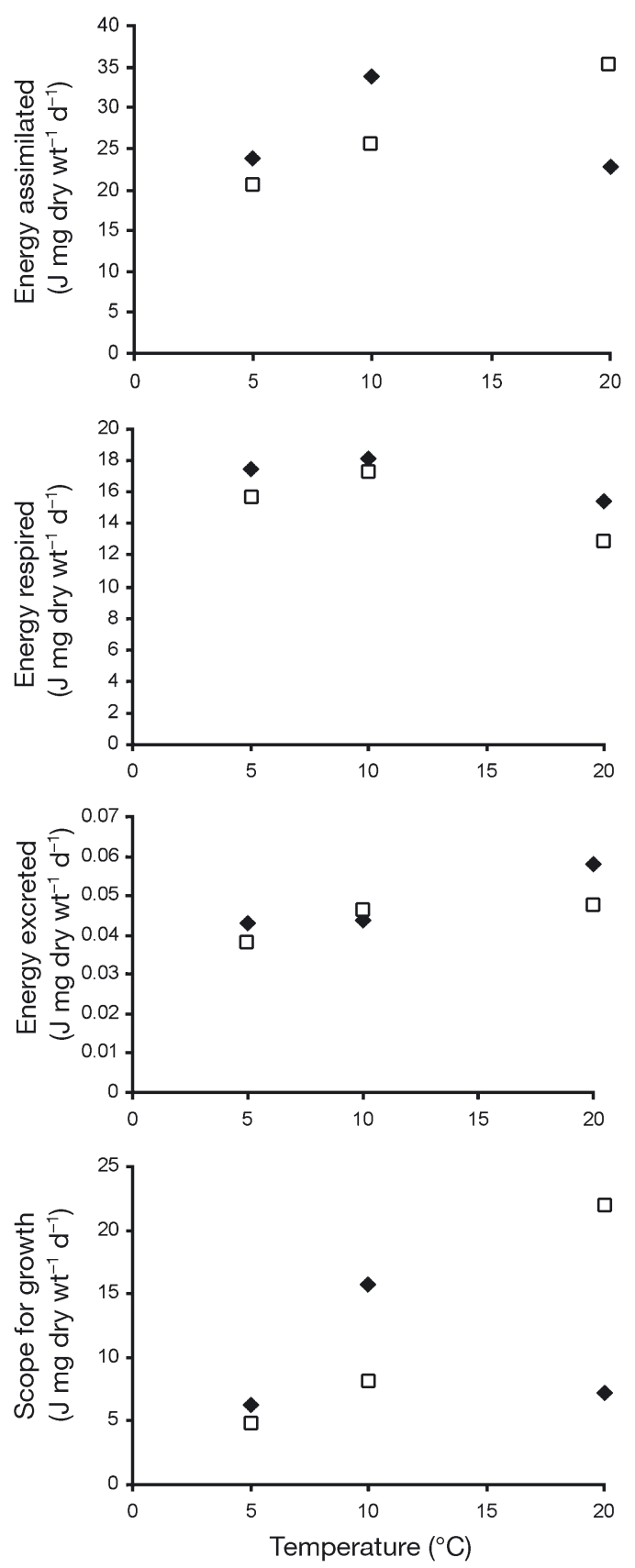

Fig. 3. Acartia bifilosa and Acartia discaudata. Scope for growth response to temperature $(\bullet=A$. bifilosa, $\square=A$. discaudata) and assimilation performance. However, there was no statistically significant difference between the intra- or interspecific respiration rates recorded at the experimental temperatures (Fig. 3).

As temperature increased, so did the excretion rate of both Acartia bifilosa and A. discaudata (Table 2),

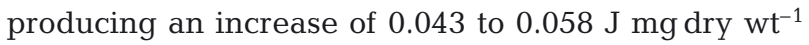
$\mathrm{d}^{-1}$ and from 0.038 to $0.048 \mathrm{~J}$ mg dry $\mathrm{wt}^{-1} \mathrm{~d}^{-1}$ respectively. Again there were no inter- or intraspecific significant differences in the excretion rate measured at the 3 temperatures.

Considered as a single parameter, the SfG of an individual should increase as the 'environment' approaches optimum. Although it was not possible to test the results statistically, it was clear that Acartia bifilosa had a substantially higher SfG at $10^{\circ} \mathrm{C}$, while the SfG of $A$. discaudata was consistently positively correlated with temperature, so that at $20^{\circ} \mathrm{C}$ it was higher than at 5 and $10^{\circ} \mathrm{C}$ (Fig. 3). With no significant differences within the excretion or respiration results, the SfG was obviously more dependent on the amount of food ingested, and ultimately the amount of energy assimilated by the individual. Indeed, the temperature-induced pattern of SfG most closely mirrored the pattern of the amount of energy assimilated (Fig. 3), suggesting that it, of all the energy-parameters measured, is the best indicator of stress.

\section{DISCUSSION}

There are a very limited number of critical experimental investigations into the effect of photoperiod on copepod diapause (Marcus 1979, 1980, 1982). The summer diapause response of Southampton Water Acartia bifilosa is triggered by a photoperiod change between 12:12 and 13:11 h light:dark schedules, and this is comparable to the light regime it would experience during the summer. A. bifilosa produces diapause eggs from May to July, before it disappears from the water column until November (Castro-Longoria 1998). Unlike Labidocera aestiva, which took 1 to 2 wk to fully adjust from subitaneous to diapause egg production (Marcus 1982), A. bifilosa diapause response is relatively rapid. Animals taken directly from the field, where they were subject to an ambient 11:13 h light:dark regime, and given no time to acclimatise to laboratory conditions, produce $37 \%$ diapause eggs within $2 \mathrm{~d}$ at a 13:11 h light:dark regime. Diapause egg production continues to increase dramatically over the period of the experiment, reaching $100 \%$ after only $8 \mathrm{~d}$ in some replicates. Some, if not all, of the A. bifilosa females can therefore switch the type of egg they produce very quickly. Total egg production, although low compared with some laboratory 
studies, compares well with the $A$. bifilosa egg production rate values for March of $3.1 \pm 1.3$ eggs female ${ }^{-1} \mathrm{~d}^{-1}$ reported by Castro-Longoria (1998). Egg production was not monitored for individual females, and the eggs collected were a mixture of subitaneous and diapause types, so it is unclear whether, like $L$. aestiva (Marcus 1982) and Anomalocera patersoni (Ianora \& Santella 1991), A. bifilosa has a transitional phase where both egg types are produced, or if it has an all-or-nothing response. The latter is unlikely however, as experimentally induced diapause (Table 2) was clearly influenced by a cumulative input of long day-length cycles, producing an increase in the number of diapause eggs over time.

Photoperiod is often accompanied by other, secondary factors governing diapause, and temperature generally plays a part in diapause induction in terrestrial insects, but its role for zooplankton is less consistent (Grice \& Marcus 1981, Hairston et al. 1990). Marcus (1979) found a strong correlation between temperature and the type of egg produced by Labidocera aestiva, but the compensatory role of temperature is equivocal for Acartia bifilosa. At the threshold day length of 13:11 h light:dark, a low incubation temperature of $5^{\circ} \mathrm{C}$ does not inhibit diapause egg production (Table 1); however at a 12:12 h light:dark photoperiod, a small number of diapause eggs are produced after $6 \mathrm{~d}$ at higher incubation temperatures of 14 and $18^{\circ} \mathrm{C}$. This suggests that if 'summer temperatures' come early, and so do associated changes in the pelagic ecosystem, leading to a phytoplankton bloom and increased zooplankton and gelatinous-predator numbers, then $A$. bifilosa can initiate production of diapause eggs, albeit in low numbers, to begin an egg pool to sustain the species. Such a flexible diapause response would help to ensure the maximum numbers of animals in next year's population.

Temperature clearly plays some role in initiating Acartia bifilosa diapause, but the ultimate reason behind its disappearance from the water column during the warmer summer period is likely to be predator avoidance (Lucas \& Williams 1995, Slusarczyk 1995) or an attempt to avoid the higher temperatures. SfG was used to identify the basic metabolic response of $A$. bifilosa and $A$. discaudata to temperature, as an additional monitor of $A$. bifilosa's egg production patterns. It is reported that the main limiting factor of crustacean $\mathrm{SfG}$ in excess food conditions is the amount of energy assimilated from the food ingested (Bayne et al. 1985, Naylor et al. 1989, Maltby et al. 1990). A. bifilosa certainly ingests more food at $10^{\circ} \mathrm{C}$ than at the other 2 experimental temperatures (Table 2 ), and it also consumes significantly more food at $10^{\circ} \mathrm{C}$ than $A$. discaudata. In contrast, $A$. discaudata ingests significantly more food at $20^{\circ} \mathrm{C}$ and its feeding rate is significantly greater than that of $A$. bifilosa at this higher temperature. These results correspond well with Mills (1997),

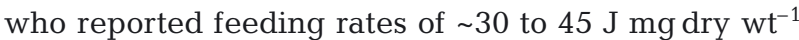
$\mathrm{d}^{-1}$ for $A$. bifilosa fed over a range of temperatures ( 5 to $20^{\circ} \mathrm{C}$ ). In contrast, in terms of cells eaten mg dry $\mathrm{wt}^{-1}$ $\mathrm{d}^{-1}$, the present results are 2 to 3 orders of magnitude larger than those reported for A. clausi (Ayukai 1987) and $A$. tonsa (Cowles et al. 1988). However, in both of these cases the initial food concentration was several orders of magnitude lower than in the present study, and copepod ingestion is known to increase linearly with food concentration (Frost 1972, Gaudy 1974). The current Acartia feeding rates should only be taken in the context of the SfG assay.

Reflecting the ingestion pattern, the assimilation efficiency for Acartia bifilosa is significantly higher at 10 than at $20^{\circ} \mathrm{C}$ (Table 2). Efficiency increases with increasing temperature in A. discaudata, but with no significant difference in measured assimilation efficiencies its energy intake depends solely on the amount of food ingested. The results are comparable to other copepod assimilation efficiencies reported (Gaudy 1974, Abou Debs 1984). A. bifilosa clearly shows optimal grazing and energy assimilation at $10^{\circ} \mathrm{C}$, while $A$. discaudata energy assimilation simply reflects incubation temperature. This metabolic strategy would go some way to explaining why A. discaudata is present in Southampton Water all year round, while A. bifilosa diapauses over summer.

Although Hirche (1987) observed fluctuations in respiration rate with temperature for Calanus glacialis, Metridia longa, C. hyperboreus and C. finmarchicus, Lampitt \& Gamble (1982) reported that respiration in Oithona nana was actually temperature-independent. For both Acartia congeners, respiration is responsible for up to 76.4 and $83.7 \%$ of energy 'lost' in A. discaudata and $A$. bifilosa respectively. For both species, respiration rate is lowest at $20^{\circ} \mathrm{C}$ and highest at $10^{\circ} \mathrm{C}$, but the results are not statistically significant. The respiration rates are comparable but higher than those reported by Mills (1997), who recorded rates of $\sim 2.5 \mathrm{~J} \mathrm{mg}$ dry $\mathrm{wt}^{-1} \mathrm{~d}^{-1}$ for $A$. bifilosa. Abou Debs (1984) reported

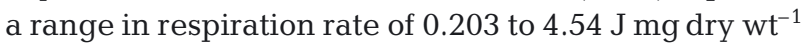
$\mathrm{d}^{-1}$ for Temora stylifera, but the experimental copepods were not fed to satiation prior to the investigation. Acartia populations in the current investigation were well fed and should not be unduly stressed by a lack of food during the experimental period (Kiørboe et al. 1985). Since respiration rate increases with food intake (Gaudy 1974, Abou Debs 1984, Kiørboe et al. 1985), the elevated respiration rates seen in Acartia are probably a reflection that the copepods were fed to satiation for $24 \mathrm{~h}$ prior to measurement.

There were no significant differences in excretion rate at the 3 experimental temperatures for either 
copepod. The energy lost through this component is almost negligible when compared to the other factors of the SfG assay, at only $\sim 0.05 \mathrm{~J}$ mgdry $\mathrm{wt}^{-1} \mathrm{~d}^{-1}$ for both species. These rates compare favourably with values for Acartia bifilosa (Mills 1997), A. clausi (Harris 1959) and Temora stylifera (Abou Debs 1984).

Reflecting the individual metabolic parameters, and driven by the pattern of energy assimilation, the SfG for each species is clearly influenced by temperature, with Acartia bifilosa SfG at $10^{\circ} \mathrm{C}>20^{\circ} \mathrm{C}=5^{\circ} \mathrm{C}$ and $A$. discaudata $\mathrm{SfG}$ at $20^{\circ} \mathrm{C}>10^{\circ} \mathrm{C}>5^{\circ} \mathrm{C}$ (Table 2). The SfG of $A$. discaudata increases virtually linearly with temperature (Fig. 3), suggesting a rather straightforward response to ambient field temperatures, whereas $A$. bifilosa SfG at 20 and $5^{\circ} \mathrm{C}$ are similar, but approximately half the $\mathrm{SfG}$ at $10^{\circ} \mathrm{C}$. In Southampton Water the temperature ranges from $2^{\circ} \mathrm{C}$ in winter and fluctuates between 10 and $20^{\circ} \mathrm{C}$ from May to September. At the identified optimum temperatures, $10^{\circ} \mathrm{C}$ for $\mathrm{A}$. bifilosa and $20^{\circ} \mathrm{C}$ for $A$. discaudata, the maximum amount of energy is available to the individual for gametic and somatic growth. The largest $A$. bifilosa adults in the Bothnian Sea were recorded in June, when the water temperature was $\sim 8^{\circ} \mathrm{C}$ (Viitasalo et al. 1995). Once adult, available energy goes into reproductive effort and $A$. bifilosa clearly assimilates more energy at $10^{\circ} \mathrm{C}$, and also produces more eggs, than at $20^{\circ} \mathrm{C}$ (CastroLongoria 1998). A photoperiod of 13:11 h light:dark triggers diapause in Southampton Water A. bifilosa, and given its metabolic performance and greatly reduced SfG between 10 and $20^{\circ} \mathrm{C}$, the ultimate reason behind its over-summer diapause strategy is likely to be an attempt to avoid the higher temperatures of this season. A. bifilosa can feed successfully on a wide spectrum of food, has a superior ability to switch its diet focus throughout the year and is known to supplement its diet with detritus over winter (Chinnery 2002). Competition is also greatly reduced during the winter months and so, even with its low SfG, it has a better chance of survival.

Acknowledgements. F.E.C. was funded by the Natural and Environmental Research Council (NERC). Many thanks to Mrs. K. Davis for producing the figures in this manuscript.

\section{LITERATURE CITED}

Abou Debs C (1984) Carbon and nitrogen budget of the calanoid copepod Temora stylifera: effect of concentration and composition of food. Mar Ecol Prog Ser 15:213-223

Alekseev VR, Starobogatov YI (1996) Types of diapause in Crustacea: definitions, distribution, evolution. Hydrobiologia 320:15-26

Ayukai T (1987) Discriminate feeding of the calanoid copepod Acartia clausi in mixtures of phytoplankton and inert particles. Mar Biol 94:579-587
Ban S, Minoda T (1994) Induction of diapause egg production in Eurytemora affinis by their own metabolites. In: Ferrari FD, Bradley BP (eds) Ecology and morphology of copepods. Kluwer Academic Publishers, Dordrecht, p 185-189

Bayne BL, Brown DA, Burns K, Dixon DR and 6 others (1985) The effects of stress and pollution on marine animals. Praeger Publishers, New York

Castro-Longoria E (1998) Seasonal and spatial distribution patterns of the congeneric group Acartia in the SolentSouthampton Water estuarine system, with special reference to aspects of their fecundity. $\mathrm{PhD}$ thesis, University of Southampton

Castro-Longoria E, Williams JA (1999) The production of subitaneous and diapause eggs: a reproductive strategy for Acartia bifilosa (Copepoda:Calanoida) in Southampton Water, UK. J Plankton Res 21:65-84

Checkley DM Jr, Dagg MJ, Uye S (1992) Feeding, excretion and egg production by individuals and populations of the marine planktonic copepods, Acartia spp. and Centropages furcatus. J Plankton Res 14:71-96

Chinnery FE (2002) The feeding and reproductive strategies of Acartidae in Southampton Water. PhD thesis, University of Southampton

Conover RJ (1957) Notes on the seasonal distribution of zooplankton in Southampton Water, with special reference to the genus Acartia. Ann Mag Nat Hist 12:63-67

Conover RJ (1966) Factors affecting the assimilation of organic matter by zooplankton and the question of superfluous feeding. Limnol Oceanogr 11:346-354

Cowles TJ, Olson RJ, Chisholm SW (1988) Food selection by copepods: discrimination on the basis of food quality. Mar Biol 100:41-49

Crisp DJ (1971) Energy flow measurements. In: Holme NA, McIntyre AD (eds) Methods for the study of the marine benthos. Blackwell Scientific Publications, Oxford, p 197-279

Elliott JM, Davison W (1975) Energy equivalents of oxygen consumption in animal energetics. Oecologia 19:195-201

Frost BW (1972) Effects of size and concentration of food particles on the feeding behaviour of the marine planktonic copepod Calanus pacificus. Limnol Oceanogr 17:805-815

Gaudy R (1974) Feeding four species of pelagic copepods under experimental conditions. Mar Biol 25:125-141

Gauld DT (1951) The grazing rates of planktonic copepods. J Mar Biol Assoc UK 29:695-706

Grice GD, Gibson VR (1975) Occurence, viability and significance of resting eggs of the calanoid copepod Labidocera aestiva. Mar Biol 31:335-337

Grice GD, Gibson VR (1977) Resting eggs in Pontella meadi (Copepoda:Calanoida). J Fish Res Board Can 34:410-412

Grice GD, Marcus NH (1981) Dormant eggs of marine copepods. Oceanol Mar Biol Annu Rev 19:125-140

Hairston NG, Dillon TA, De Stasio BT (1990) A field test for the cues of diapause in a freshwater copepod. Ecology 71 : 2218-2223

Harris E (1959) The nitrogen cycle in Long Island Sound. Bull Bingham Oceanogr Collect 17:31-65

Hirche HJ (1987) Temperature and plankton. II. Effect on respiration and swimming activity in copepods from the Greenland Sea. Mar Biol 94:347-356

Ianora A, Santella L (1991) Diapause embryos in the neustonic copepod Anomalocera patersoni. Mar Biol 108:387-394

Ianora A, Poulet SA, Miralto A, Grottoli R (1996) The diatom Thalassiosira rotula affects reproductive success in the copepod Acartia clausi. Mar Biol 125:279-286

Irigoien X, Castel J (1995) Feeding rates and productivity of the copepod Acartia bifilosa in a highly turbid estuary; the 
Gironde (SW France). Hydrobiologia 311:115-125

Irigoien X, Castel J, Sautour B (1993) In situ grazing activity of planktonic copepods in the Gironde estuary. Cah Biol Mar 34:225-237

Johnson JK (1980) Effects of temperature and salinity on production and hatching of dormant eggs of Acartia californiensis (Copepoda) in an Oregon estuary. Fish Bull US 77:567-584

Kasahara S, Uye S (1979) Calanoid copepod eggs in seabottom muds. V. Seasonal changes in hatching of subitaneous and diapause eggs of Tortanus forcipatus. Mar Biol 55:63-68

Kifle D (1992) Seasonal and spatial variations in species composition, abundance, biomass and primary production of phytoplankton in Southampton Water. PhD thesis, University of Southampton

Kiørboe T, Möhlenberg F, Hamburger K (1985) Bioenergetics of the plankton copepod A. tonsa: relation between feeding, egg production and respiration, and composition of specific dynamic action. Mar Ecol Prog Ser 26:85-97

Lampitt RS, Gamble JC (1982) Diet and respiration on the small planktonic marine copepod Oithona nana. Mar Biol 66:185-190

Lucas A (1996) Bioenergetics of aquatic animals. Taylor \& Francis, London

Lucas C, Williams JA (1995) Gelatinous predators and their potential impact on the mesozooplankton community of Southampton Water. In: Eleftheriou A, Ansell AD, Smith CJ (eds) Biology and ecology of shallow coastal waters, Fredensborg. Olsen \& Olsen, Fredensborg, p 245-252

Maltby L, Naylor C, Calow P (1990) Effect of stress on a freshwater benthic detritivore: scope for growth in Gammarus pulex. Ecotoxicol Environ Saf 19:285-291

Marcus NH (1979) On the population biology and nature of diapause of Labidocera aestiva (Copepoda:Calanoida). Biol Bull 157:297-305

Marcus NH (1980) Photoperiodic control of diapause in the marine calanoid copepod Labidocera aestiva. Biol Bull 159:311-318

Marcus NH (1982) Photoperiodic and temperature regulation of diapause in Labidocera aestiva (Copepoda:Calanoida). Biol Bull 162:45-52

Editorial responsibility: Otto Kinne (Editor),

Oldendorf/Luhe, Germany
Mills JOR (1997) The influence of temperature and salinity stress on the scope for growth of a Calanoid copepod, Acartia bifilosa in Southampton Water. BSc thesis, University of Southampton

Naylor C, Maltby L, Calow P (1989) Scope for growth in Gammarus pulex, a freshwater benthic detritivore. Hydrobiologia 188/189:517-523

Nival P, Nival S (1976) Particle retention efficiencies of an herbivorous copepod, Acartia clausi (adult and copepodite stages): effects on grazing. Limnol Oceanogr 21:24-38

Raymont JEG, Carrie BGA (1964) The production of zooplankton in Southampton Water. Int Rev Ges Hydrobiol 49:185-232

Santer B, Lampert W (1995) Summer diapause in cyclopoid copepods-adaptive responses to a food bottle neck. J Anim Ecol 64:600-613

Sautour B, Castel J (1995) Comparative spring distribution of zooplankton in three macrotidal European estuaries. Hydrobiologia 311:139-151

Slusarczyk M (1995) Predator induced diapause in Daphnia. Ecology 76:1008-1013

Solorozano L (1969) Determination of ammonia in natural waters by the phenolhypochlorite method. Limnol Oceanogr 14:799-801

Tester PA, Turner JT (1990) How long does it take copepods to make eggs? J Exp Mar Biol Ecol 141:169-182

Uye S (1985) Resting egg production as a life history strategy of marine planktonic copepods. Bull Mar Sci 37:440-449

Viitasalo M (1992) Calanoid resting eggs in the Baltic Sea: implications for the population dynamics of $A$. bifilosa (Copepoda). Mar Biol 114:397-405

Viitasalo M, Koski M, Pellikka K, Johnson J (1995) Seasonal and long term variations in the body size of planktonic copepods in the Northern Baltic Sea. Mar Biol 123: $241-250$

Winberg GG (1960) Rate of metabolism and food requirements of fishes. Fish Res Board Can Trans Ser 194:202

Zillioux EJ, Gonzalez JG (1970) Egg dormancy in a neritic calanoid copepod and its implications to overwintering in boreal estuaries. In: Battaglia B (ed) 5th European Marine Biology Symposium, Venice, 5-11 Oct 1970. Piccin, Padua, p 217-230

Submitted: October 11, 2002; Accepted: June 26, 2003

Proofs received from author(s): November 5, 2003 